\title{
COMPARATIVE ANALYSIS OF DNA ISOLATED FROM FISH SAMPLES BY THREE DIFFERENT EXTRACTION PROTOCOLS
}

\author{
Oduoye $\mathrm{OT}^{1 *}$, Ajayi $\mathrm{DA}^{1}$, Oluwasanya $\mathrm{OA}^{1}$, Hassan $\mathrm{T}^{1}$, Olajire $\mathrm{OE}^{1}$, Coker $\mathrm{DO}^{1}$, Sunday $\mathrm{A}^{1}$, \\ Ayekun $\mathrm{OA}^{1}$, Tola-Fabunmi $\mathrm{AS}^{1}$, Nden $\mathrm{DS}^{1}$, Olufeagba $\mathrm{SO}^{2}$, Aladele $\mathrm{SE}^{1}$
}

${ }^{1}$ National Centre for Genetic Resources and Biotechnology (NACGRAB), PMB 5382, Ibadan.

${ }^{2}$ Department of Fisheries and Aquaculture, University of Agriculture Makurdi, Nigeria

Received - July 21, 2020; Revision - September 28, 2020; Accepted - October 20, 2020

Available Online - October 25, 2020

DOI: http://dx.doi.org/10.18006/2020.8(5).644.653

\author{
KEYWORDS \\ DNA Extraction Protocols \\ Barcoding \\ Genetic conservation \\ Fresh water fishes \\ Cytochrome B
}

\begin{abstract}
The studies on fish genetic diversity and its conservation in Nigeria are still at its preliminary stages. The country needs to document the diversities of all the water bodies and also embark on a DNA barcoding project for rapid identification of the enormous populations and consequent deposition in the global genebank for references. All molecular studies usually start with the isolation, purification, and recovery of DNA and this usually depends on the types of tissue, mode of sample collection, the medium of storage, duration of storage, and used extraction protocols. The current study embarked on fish collection in four major freshwater habitats as a preliminary study to a proposed fish barcoding project and to comparatively determine the extraction protocol that will be cost-effective, fast, safe, and yield adequate molecular materials for downstream amplification, cloning, and sequencing reactions. In the current study, three DNA extraction protocols, Zymo Research Kit (ZR), modified conventional SNET method, and modified UreaSDS Method were compared to establish the best DNA extraction method from freshwater fishes. Sixtytwo (62) fish samples were collected belonging to 16 different families, 23 Genera, and 32 Species. The average yield of the three protocols in terms of concentration (ng/ $\mu \mathrm{L}$ : Purity) are: ZR (30.59: 1.58); UREA, (705.49: 1.75) and SNET (562.22: 1.73). Hence, in terms of DNA concentration recovery, the sequence of the best method is UREA > SNET > ZR, and the same trend followed in the case of Purity. Statistical tests did not show any significant difference when the extraction protocols were compared among fish families. Cytochrome B gene was successfully amplified on the DNA template to confirm their suitability for further studies. The result of the study can be concluded that among the best DNA extraction methods, UREA protocol can be recommended for fish DNA extraction, this is not only cost-effective, but also gave quality yield and adequate for downstream analysis.
\end{abstract}

\footnotetext{
* Corresponding author

E-mail: solaoduoye@gmail.com (Oduoye OT)
}

Peer review under responsibility of Journal of Experimental Biology and Agricultural Sciences.

Production and Hosting by Horizon Publisher India [HPI] (http://www.horizonpublisherindia.in/).

All rights reserved.
All the articles published by Journal of Experimental Biology and Agricultural Sciences are licensed under a Creative Commons Attribution-NonCommercial 4.0 International License Based on a work at www.jebas.org.

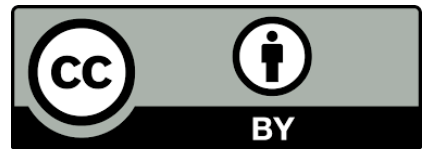




\section{Introduction}

The genetic diversity study of fish species in Nigeria is still at a rudimentary level. Not only for the documentation of all Nigerian water bodies diversities but also to embark on a serious DNA barcoding project for rapid identification of the vast populations and consequent deposition in the global genebank for references, DNA isolation and sequencing are the most necessary steps (Nwakanma et al., 2015). The North America and Canadian fish diversities have long been studied and researchers have recently obtained barcodes for up to 5,674 fish species (50 families, 178 genera, and 752 species). These data were deposited into public databases for future references (Nelson et al., 2004; April et al., 2011; Keele et al., 2014).

Molecular studies on fishes must start with exploration from their various habitat; water bodies which include the freshwater environment, brackish water bodies ( $25 \mathrm{ppm}$ salt content), and marine habitat (35 ppm salt content) with a different mode of harvesting and fishing gears (Weigt et al., 2012; Muhammad et al., 2016). Molecular studies on fish include the study of the fish genetic structure through DNA polymorphic markers. The study is are so significant to fish conservators and breeders because it assists them set priorities for conservation and demystify the influence of climate change on those species in their natural habitat (Rodriguez-Ezpeleta et al., 2013).

The recovery of high molecular weight and quality DNA from various sources of tissue samples are the basic and crucial steps in molecular biology. The quality and quantity of genomic DNA recovered from tissues influence the results of several molecular experiments including PCR, enzyme digestion and recombinant selection (Chowdhury et al., 2016; Muhammad et al., 2016). The isolation, purification and recovery of high molecular weight DNA is usually dependent on the tissue types, mode of collection, duration of storage, the medium of storage, extraction protocols among others (Wasko et al., 2003; Lagass-Pereira et al., 2016; Muhammad et al., 2016). Some of the reagents eventually contaminate the extracted genomic DNA, consequently interfere with the DNA downstream analyses (Pereira et al 2011; Naeem et al 2020). The extracted DNA that is good and uncontaminated by proteins, polysaccharides, polymerase inhibitors and nucleases is a basic prerequisite in molecular biology research such as PCR, genotyping, microarray, next-generation sequencing (Majumder et al 2011). Variation in mitochondrial DNA (mtDNA) is being adopted as a dependable tool for determining genetic diversity within and among species because the number of mtDNA is higher than the nuclear DNA and it is the best way of maternal inheritance (Widayanti et al, 2019). The selection of mitochondrial (mtDNA) centers on the fact that vertebrates show more variations in the mitochondrial genome than nuclear DNA due to rapid mutation rate and copy number per cell
(Megarani et al, 2020). Mitochondrial cytochrome b (cyt-b) gene is widely used in diversity studies to resolve divergences at many taxonomic levels; it is made up of conservative and variable regions, also one of the best known mitochondrial genes (Megarani et al., 2020).

Research works that involve fish ecological distribution, population distribution, and diversity conservation in the era of climate change will require several optimized protocols of DNA extraction to work on both archived fish samples and living tissues (Bruyn et al., 2011).

National Centre for Genetic Resources and Biotechnology (NACGRAB) is a hob in Nigeria for the conservation of all genetic resources including the fish species in Nigerian water bodies. In an attempt to develop barcode for available fish samples across the water bodies, a current pilot study was carried out to compare three DNA extraction protocols with minor modifications to determine the most suitable extraction method in terms of quality, quantity, and relatively low cost which could be employed for the vast proposed project.

\section{Materials and Methods}

Sixty-four (64) fish samples from 32 fish species (in duplicate) were collected from four freshwater bodies of Nigeria viz., Kainji Lake in Niger State (Guinea savannah), Benue River in Benue state (Guinea savannah), Asejire Dam in Osun State (Tropical rain forest) and Eleyele Dam in Oyo State (Tropical rain forest); this collection comprises 23 genera in 16 fish families (Table 1). The fishing gears used for the collection were gill net, cast net, and dragnet. In the current study, three different extraction protocols i.e. DNA from fish samples: Zymo Research kit (Espinoza et al., 2017), modified SNET method (Chowdhury et al., 2016) and modified Urea-SDS method (Dwiyitno et al., 2018) were used to extract DNA.

\subsection{Zymo Research Kit}

According to the manufacturer instructions, beta-mercaptoethanol was added to the genomic lysis buffer to a final dilution of $0.5 \%$ $(\mathrm{v} / \mathrm{v})$ : fish tissue weighing $20 \mathrm{mg}$ collected from the region of caudal peduncle was homogenized in $0.8 \mathrm{~mL}$ of genomic lysis buffer. The lysate was transferred into $2.0 \mathrm{~mL}$ centrifuge tube and centrifuged at $10,000 \mathrm{rpm}$ for 5 minutes. $300 \mu \mathrm{L}$ DNA pre-wash buffer was added to the column and spun at 10,000 rpm for 1 minute and flow through was discarded. About $400 \mu \mathrm{L}$ of g-DNA wash buffer was added to the column and centrifuged at 10,000 rpm for 1 minute, flow through discarded and the step was repeated. The zymo-spin column was transferred to a $1.5 \mathrm{~mL}$ microcentrifuge tube and $100 \mu \mathrm{L}$ DNA elution buffer was added directly to the column matrix and allowed to stand for 1 minute at 
Table 1 Fish family, species name of fresh water bodies and their ecological locations where collections were made in Nigeria

\begin{tabular}{|c|c|c|c|c|}
\hline S. N. & FAMILY & GENERA & SPECIES & LOCATION \\
\hline \multirow{3}{*}{1} & \multirow{3}{*}{ Alestidae } & Micralestes & Micralestes humilies & Kainji \\
\hline & & \multirow{2}{*}{ Alestes } & Alestes longipinis & Kainji \\
\hline & & & Alestes dentex & Benue \\
\hline 2 & Bagridae & Bagrus & Bagrus bayad & Kainji \\
\hline \multirow{7}{*}{3} & \multirow{7}{*}{ Cichlidae } & \multirow{4}{*}{ Tilapia (Coptodon) } & Tilapia zilli & Benue \\
\hline & & & Tilapia mariae & Kainji \\
\hline & & & Tilapia guinensis & Kainji \\
\hline & & & Tilapia melanotheron & Benue \\
\hline & & Oreochromis & Oreochromis niloticus & Asejire \\
\hline & & Hemichromis & Hemichromis fasciatus & Eleyele \\
\hline & & Sarotherodon & Sarotherodon galilaeus & Asejire \\
\hline 4 & Citharinidae & Citharinus & Citharinus citharus & Kainji \\
\hline 5 & Clariidae & Clarias & Clarias gariepinus & Asejire \\
\hline \multirow{2}{*}{6} & \multirow{2}{*}{ Claroteidae } & Chrysichthys & Chrysichthys nigrodigitatus & Kainji \\
\hline & & Clarotes & Clarotes laticep & Benue \\
\hline \multirow{3}{*}{7} & \multirow{3}{*}{ Cyprinidae } & \multirow{3}{*}{ Labeo } & Labeo parvus & Asejire \\
\hline & & & Labeo carensis & Kainji \\
\hline & & & Labeo senegalensis & Benue \\
\hline 8 & Distichodontidae & Distichodus & Distichodus rostratus & Asejire, Kainji \\
\hline 9 & Hepsetidae & Hepsetus & Hepsetus odoe & Asejire \\
\hline 10 & Latidae & Lates & Lates niloticus & Kainji \\
\hline 11 & Malapteruridae & Malapterurus & Malapterurus electricus & Kainji \\
\hline \multirow{3}{*}{12} & \multirow{3}{*}{ Mochokidae } & \multirow{3}{*}{ Synodotis } & Synodotis budgetti & Benue \\
\hline & & & Synodontis membranaceous & Kainji \\
\hline & & & Synodontis omias & Kainji \\
\hline \multirow{3}{*}{13} & \multirow{3}{*}{ Mormyridae } & \multirow{2}{*}{ Mormyrus } & Mormyrus rume & Benue \\
\hline & & & Mormyrus senegalensis & Asejire \\
\hline & & Hyperopisus & Hyperopisus bebe & Kainji \\
\hline 14 & Polypteridae & Polypterus & Polypterus annectens & Kainji, Kainji \\
\hline \multirow{2}{*}{15} & \multirow{2}{*}{ Schilbeidae } & Schilbe & Schilbe mystus & Asejire, Kainji \\
\hline & & Physailia & Physailia pellucida & Benue \\
\hline 16 & Tetraodontidae & Tetraodon & Tetraodon fahaka & Kainji \\
\hline TOTAL & 16 & 23 & 32 & \\
\hline
\end{tabular}

KEY: Kainji (Guinea Savannah) - 27 samples, Benue (Guinea Savannah) - 12 samples, Asejire (Tropical rain forest) - 17 samples, Eleyele (Tropical rain forest) - 6 samples

Journal of Experimental Biology and Agricultural Sciences http://www.jebas.org 
room temperature. The tube was centrifuged at $10,000 \mathrm{rpm}$ for 1 minute to elute the DNA. The eluted DNA was checked on a spectrophotometer and stored at $-20{ }^{\circ} \mathrm{C}$ for downstream analysis (Espinoza et al, 2017).

\subsection{Modified SNET Method}

Fish tissue of $100 \mathrm{mg}$ weight collected from caudal peduncle was suspended in $500 \mu \mathrm{L}$ of extraction buffer ( $20 \mathrm{mM}$ Tris- $\mathrm{HCl}, 5 \mathrm{mM}$ EDTA, $400 \mathrm{mM} \mathrm{NaCl}, 1 \%(\mathrm{w} / \mathrm{v})$ SDS, Proteinase $\mathrm{K})$, homogenized overnight at $55^{\circ} \mathrm{C}$ in a shaking incubator with oscillation of $200 \mathrm{rpm}$. An equal volume of phenol: chloroform: isoamyl Alcohol (25:24:1) was added to the lysate in a shaking incubator at room temperature for $30 \mathrm{~min}$ and centrifuged at $14,000 \mathrm{rpm}$ for $5 \mathrm{~min}$. The upper aqueous layer was transferred to a new micro-centrifuge, an equal volume of ice-cold isopropanol added and centrifuged again at 10,000 rpm for 5 minutes. Isopropanol was decanted and DNA was washed with $70 \%$ ethanol. The DNA was air-dried at room temperature for about 3 hours and re-suspended in $100 \mu \mathrm{L}$ nuclease free water (Chowdhury et al., 2016).

\subsection{Modified Urea-SDS Method}

Fish tissue sample of $100 \mathrm{mg}$ was suspended and homogenized in $400 \mu \mathrm{L}$ of TESU6 buffer(10mM Tris- $\mathrm{HCl} \mathrm{pH} 8.0+20$ mM EDTA $\mathrm{pH} 8.0+2 \% \mathrm{SDS}+6 \mathrm{M}$ Urea $+0.5 \mu \mathrm{L}$ proteinase $\mathrm{K})$. The mixture was thoroughly vortexed, then incubated at $55^{\circ} \mathrm{C}$ in a shaking incubator of $200 \mathrm{rpm}$ for $15 \mathrm{~min}$. To the lysate, $10 \mu \mathrm{L}$ of $5 \mathrm{M} \mathrm{NaCl}$ was added and mixed gently by inversion. An equal volume of phenol: chloroform: isoamyl alcohol $(25: 24: 1)$ was added, mixed by inversion, centrifuged at $10,000 \mathrm{rpm}$ for 5 minutes, and the aqueous phase collected. An equal volume of chilled isopropyl alcohol was added, tube inverted several times, and kept at $-20{ }^{\circ} \mathrm{C}$. After overnight precipitation, the mixture was centrifuged at $10,000 \mathrm{rpm}$ for 5 minutes and the supernatant was decanted. Then the DNA precipitate was washed with chilled $70 \%$ alcohol and pellet dried. The DNA pellet resuspended in $100 \mu \mathrm{L}$ of nuclease free water (Dwiyitno et al., 2018).

\subsection{Spectrophotometry and Gel-electrophoresis}

The Quality of DNA extracted was quantified with Nanodrop Spectrophotometer 2000 as well as on horizontal Agarose gel-electrophoresis. The strength of gel was $1.0 \%$, Trisborate EDTA buffer, GR-green nucleic acid stain, $1 \mathrm{~Kb}$ ladder as a marker; all from Thermo Scientific, and the gel ran for about 1 hour.

\subsection{Gene Amplification}

Polymerase Chain Reaction (PCR) was used to further authenticate the performance of the protocols used. A region on Cytochrome $\mathrm{B}$
(Cytb F: TGACTTGAAAAACCACCGTTGTTA, CytbR: CTTCGGTTTACAAGACCG) was used as a potential barcoding primer for Polymerase Chain Reaction (PCR) to amplify the complementary regions on the template DNA. The product of amplification was $1227 \mathrm{bp}$. The reaction conditions were as follow: initiation reaction at $94{ }^{\circ} \mathrm{C}$ for 2 mins, Denaturation reaction at 94 ${ }^{\circ} \mathrm{C} 20 \mathrm{sec}$, Annealing reaction at $55{ }^{\circ} \mathrm{C}$ for $25 \mathrm{sec}$., elongation reaction at $72{ }^{\circ} \mathrm{C}$ for $30 \mathrm{sec}$. and final elongation reaction was at 72 ${ }^{\circ} \mathrm{C}$ for 10 mins. The reaction condition was finally held at $4{ }^{\circ} \mathrm{C}$ (Espinoza et al, 2017).

\subsection{Statistical Analysis}

The statistical packages used for this analysis were Microsoft excel 2013 and SPSS 16.1 (Kandyliari et al, 2020).

\section{Results and Discussion}

Fresh water fish diversity needs documentation and barcoding attention in Nigeria. There are many water bodies in Nigeria that have not been explored for their diversity and many species are already going to extinction. Adequate information about their past and present abundance would inform proper conservation strategies before they are lost to climate change exacerbation (Adaka et al., 2016). This pilot study precedes a barcoding project underway. Samples were randomly collected in four water bodies and the result of the diversity was encouraging. The result of 23 genera encountered among 32 species is relatively diverse and we hope to gather large populations in the proposed barcoding work (Table 1). It has been documented that there are inhibitor compounds in a lot of reagents used for DNA extraction that can interfere with PCR process by decreasing or even absolutely inhibiting the activity of DNA polymerase (Piskata et al., 2017) but optimal use, according to the design of the protocol gives adequate yield for downstream analysis (Sajali et al., 2018). In addition to reagent inhibition, biomolecular differences also contribute to the variation of DNA purity and concentration for molecular analysis because biomolecular composition varies within species of the same genus and among genera of the same or different families. The factors responsible include but are not limited to environmental influences such as salinity and temperature, effects of diet, and seasonal variation (Habib et al., 2003; Osibona et al., 2009; Keriko et al., 2010).

The result of DNA concentration and purity mean values across the 3 protocol used are in figures 2 and 3 respectively. The mean value in figure 1 revealed that Urea- SDS has the highest recovered DNA concentration (Urea-SDS 746.70; SNET 468.84; ZR 40.68)ng/ $\mu \mathrm{L}$. At the same time figure 2 (Urea-SDS 1.76; SNET 1.75; ZR 1.57) revealed the results of Nanodrop spectrophotometer as the purity of the extracted DNA. According to different authors, the best value usually ranges between 


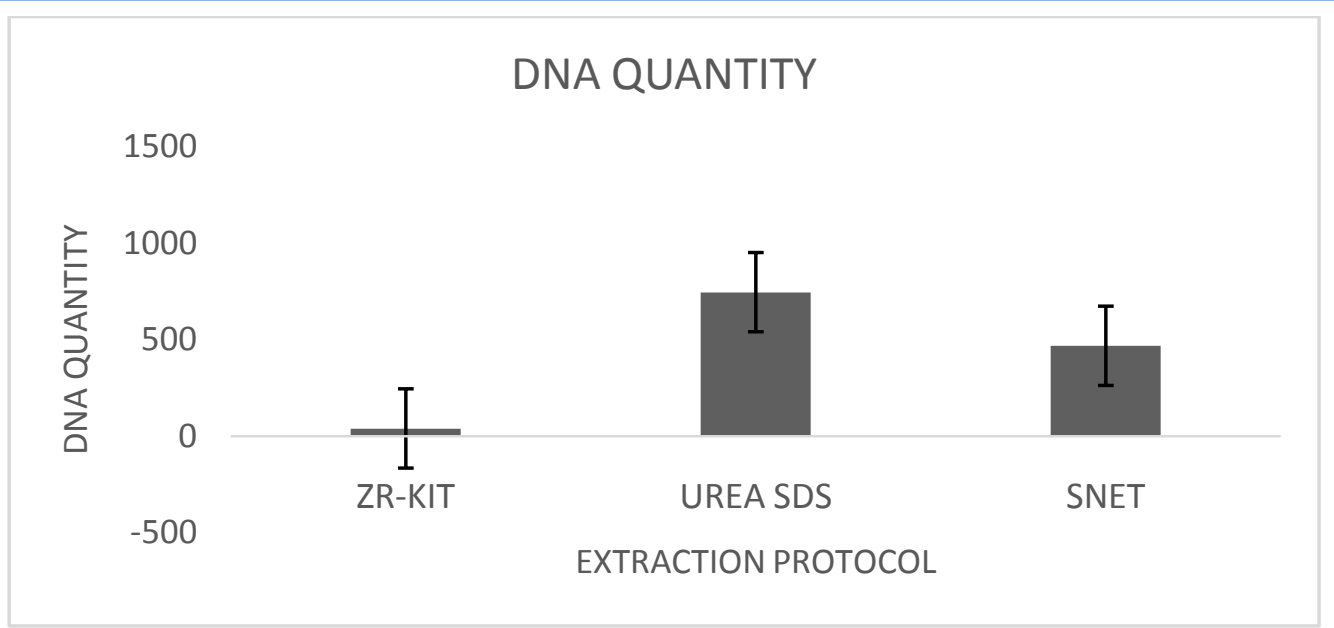

Figure 1 Mean values of DNA quantity compared across the three protocols used

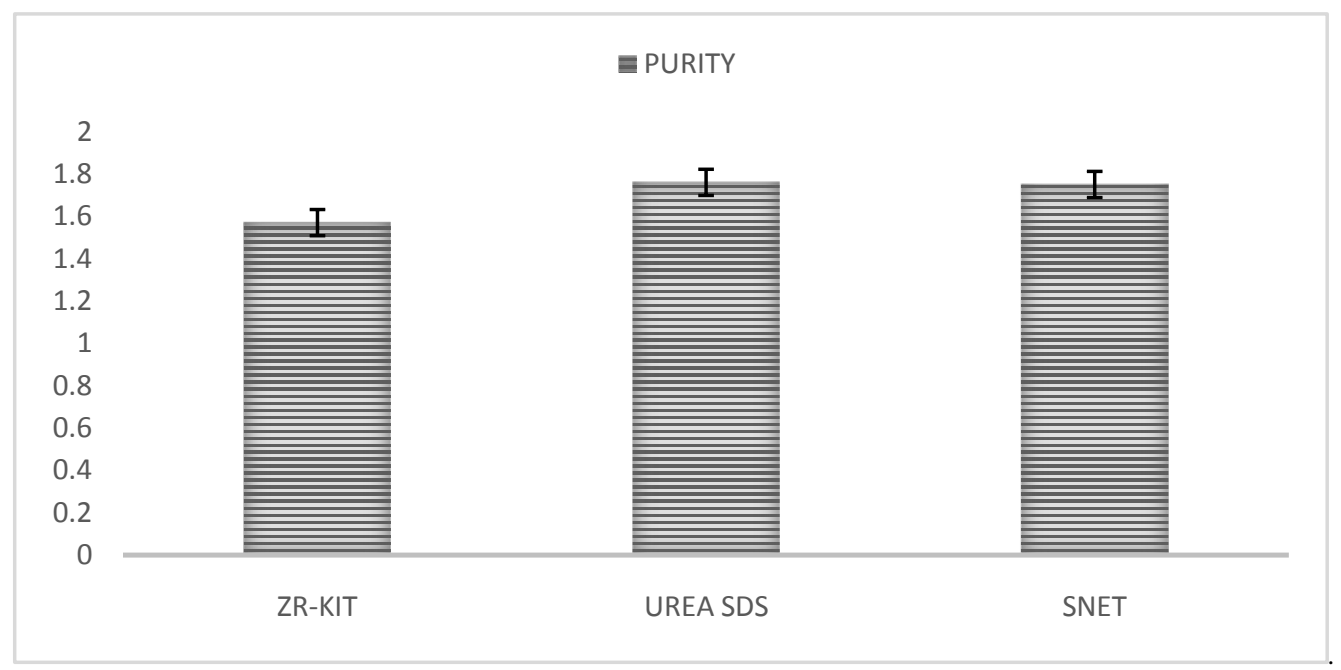

Figure 2 Mean values of DNA Purity compared across the three protocols used

1.8 and 2.0 or 2.2 (Parpinelli \& Ribeiro, 2009; Lagass-Pereira et al., 2016). Considering the three protocols used in this study, UreaSDS has the highest value of 1.76 . This was closely followed by SNET which has a value 1.75 while the least was reported with Zymo Research (1.57 Purity).

The DNA concentration and purity with relation to fish collection location or water body revealed a different pattern of the result. Figures 3 and 4 revealed that fish collection from Eleyele dam has the highest value of DNA concentration across the 3 protocols used; fish collected from this dam have values as $1295.67 \mathrm{ng} / \mu \mathrm{L}$ in SNET , $954.58 \mathrm{ng} / \mu \mathrm{L}$ with Urea-SDS, and $236.30 \mathrm{ng} / \mu \mathrm{L}$ with ZR. Among these three methods, SNET has the highest DNA concentration in Eleyele dam (1295.67 ng/ $\mu \mathrm{L})$, while Urea-SDS has the highest concentration both in Asejire (750.20 ng/ $\mu \mathrm{L})$ and Kainji dam(731.1 ng/ $\mu \mathrm{L})$.
On the other hand, the purity distribution pattern showed that Eleyele dam has the closest range of purity (Urea-SDS 1.90; SNET 1.86; ZR 1.62) around the standard value of 1.80 as earlier discussed (Figure 4). The purity of DNA recovered among the samples collected from Benue River is relatively lowest. All the samples collected were stored in absolute ethanol from the field before laboratory analysis. However, the Benue samples were collected, stored on ice, and transported over a long distance before arriving at the laboratory for tissue collection and storage in ethanol. It was observed that the tissues have started to degrade which must be responsible for the low yield of DNA extracted. Muhammad et al. (2016) have reported the suitability of absolute ethanol for the storage of tissues before DNA extraction over storage on ice due to the activities of nucleases in the cell leading to nucleic acid degradation. 


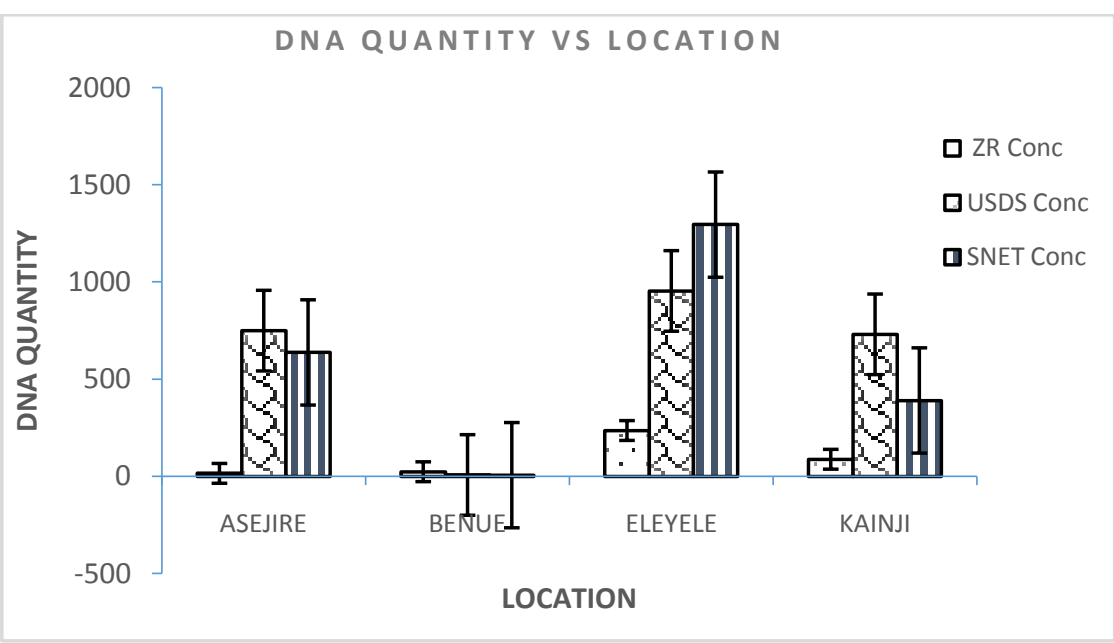

Figure 3 Mean values of DNA concentration compared across the four locations

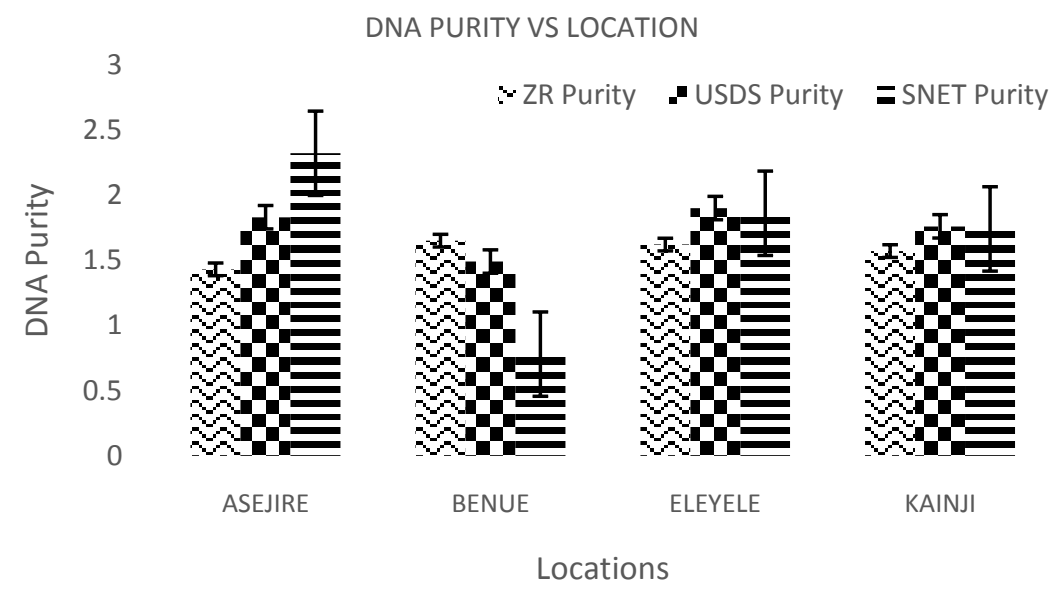

Figure 4 Mean values of DNA Purity compared across the four locations

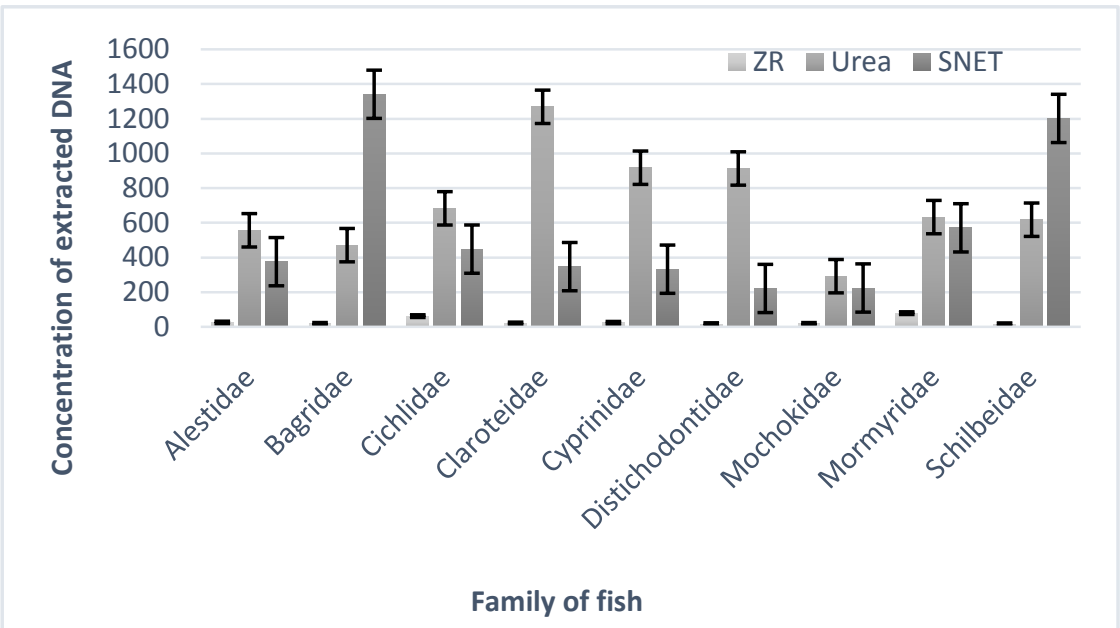

Figure 5 Mean values of DNA Concentration for 3 extraction protocol compared across the fish families
DNA concentration and purity as related to the family of fishes gave a different perspective to the study because of the variation in the biomolecular composition of various families as earlier discussed. Figure 5 showed the concentration of extracted DNA for the 3 extraction protocols across the fish families. The figure shows that urea protocol had the highest concentration for all the fish families except for families Bagridae and Schilbeidae where SNET protocol had the highest concentration. ZR protocol had the least concentration for all the fish families. However, the statistical analysis in table 2 revealed that results for different families across the protocols are not significantly different. In support of recent findings by Oosting et al. (2020), the efficiency of the protocol used and the technical proficiency of the researcher plays an important role in the recovered DNA across fish families (Jasbeer et al., 2009).

Furthermore, figure 6 revealed the purity of the extracted DNA for the 3 extraction protocols across the fish families. The figure shows slight differences in the purity of the extracted DNA among the 3 extraction protocols for all the fish families. The results are in agreement with Jasbeer et al(2009) and Oosting et al (2020). The purity of DNA extracted by the protocols have been reported to be good according to various authors: Urea-SDS method was reported by Dwiyitno et al. (2018), SNET method by Chowdhury et al. (2016), and Zymo Research kit by Espinoza et al. (2017).

To have the best sense of judgment and best deduction from all similar values for different protocols, their arithmetic means were compared for statistical inferences. Table 2 and 3 are the results of mean separation for the analysis of variance (ANOVA) showing a comparison in the concentration and 
Table 2 ANOVA result showing significant difference in the concentration and purity of the extracted DNA among the fish families and the extraction protocols

\begin{tabular}{|c|c|c|c|c|c|c|}
\hline Source & $\begin{array}{c}\text { Dependent } \\
\text { Variable }\end{array}$ & $\begin{array}{c}\text { Type III Sum of } \\
\text { Squares }\end{array}$ & df & Mean Square & $\mathrm{F}$ & Sig. \\
\hline \multirow{2}{*}{ Corrected Model } & Concentration & 19222591.019 & 26 & 739330.424 & 2.600 & .000 \\
\hline & Purity & 3.962 & 26 & .152 & .964 & .521 \\
\hline \multirow{2}{*}{ Intercept } & Concentration & 19584604.353 & 1 & 19584604.353 & 68.886 & .000 \\
\hline & Purity & 298.664 & 1 & 298.664 & 1888.293 & .000 \\
\hline \multirow{2}{*}{ Family } & Concentration & 1831106.333 & 8 & 228888.292 & .805 & $.599^{\mathrm{ns}}$ \\
\hline & Purity & 1.072 & 8 & .134 & .847 & $.563^{\mathrm{ns}}$ \\
\hline \multirow{2}{*}{ Protocols } & Concentration & 8814587.256 & 2 & 4407293.628 & 15.502 & $.000 * *$ \\
\hline & Purity & .495 & 2 & .247 & 1.564 & $.213^{\mathrm{ns}}$ \\
\hline \multirow{2}{*}{ Family * Protocols } & Concentration & 5064488.451 & 16 & 316530.528 & 1.113 & $.349^{\mathrm{ns}}$ \\
\hline & Purity & 1.959 & 16 & .122 & .774 & $.712^{\mathrm{ns}}$ \\
\hline \multirow{2}{*}{ Error } & Concentration & 39234052.862 & 138 & 284304.731 & & \\
\hline & Purity & 21.827 & 138 & .158 & & \\
\hline \multirow{2}{*}{ Total } & Concentration & 86050156.640 & 165 & & & \\
\hline & Purity & 495.425 & 165 & & & \\
\hline \multirow{2}{*}{ Corrected Total } & Concentration & 58456643.881 & 164 & & & \\
\hline & Purity & 25.789 & 164 & & & \\
\hline
\end{tabular}

**: Significant at $1 \%(\mathrm{p}<0.01)$ level; ns: Not significant at $5 \%(\mathrm{p}>0.05)$ level

Table 3 Mean separation result comparing the concentration and purity of the extracted DNA among the fish families

\begin{tabular}{|ccc|}
\hline Family & Concentration & Purity \\
\hline Alestidae & $319.08 \pm 137.67^{\mathrm{a}}$ & $1.528 \pm 0.10^{\mathrm{a}}$ \\
\hline Bagridae & $609.40 \pm 217.67^{\mathrm{a}}$ & $1.692 \pm 0.16^{\mathrm{a}}$ \\
\hline Cichlidae & $397.65 \pm 67.17^{\mathrm{a}}$ & $1.711 \pm 0.05^{\mathrm{a}}$ \\
\hline Claroteidae & $544.83 \pm 137.67^{\mathrm{a}}$ & $1.701 \pm 0.10^{\mathrm{a}}$ \\
\hline Cyprinidae & $424.36 \pm 137.67^{\mathrm{a}}$ & $1.751 \pm 0.10^{\mathrm{a}}$ \\
\hline Distichodontidae & $383.21 \pm 217.67^{\mathrm{a}}$ & $1.942 \pm 0.16^{\mathrm{a}}$ \\
\hline Mochokidae & $177.81 \pm 137.67^{\mathrm{a}}$ & $1.675 \pm 0.10^{\mathrm{a}}$ \\
\hline Mormyridae & $427.45 \pm 116.35^{\mathrm{a}}$ & $1.672 \pm 0.08^{\mathrm{a}}$ \\
\hline Schilbeidae & $611.10 \pm 177.73^{\mathrm{a}}$ & $1.539 \pm 0.13^{\mathrm{a}}$ \\
\hline
\end{tabular}

Values represent mean \pm standard error. Values along the same column with the same superscript are not significantly different at $5 \%$ ( $p>0.05$ ) level.

purity of the extracted DNA based on the family of the fish. The result shows that the concentration of the extracted DNA varied from 177.81 to 611.10 with the highest value recorded in the members of Schilbeidae family while the least value was recorded in the family Mochokidae. The results of the study revealed that the concentration of the extracted DNA did not differ significantly among the fish families at $5 \%(p>0.05)$ level. This suggests that the variation in biomolecular composition such as polysaccharides and lipids across fish families is not a plausible determinant of observed differences in purity and concentration of extracted DNA as was discussed earlier by Jasbeer et al, 2009.
Table 4 is the result of the means separations for the analysis of variance (ANOVA) showing a comparison in the concentration and purity of extracted DNA based on the protocol used for extraction. The result shows that the concentration of the extracted DNA varied from 30.59 to 705.49 with the highest concentration recorded in Urea while the least concentration was recorded in ZR. These results revealed that the concentration of the extracted DNA differed significantly among the 3 extraction protocols at $1 \%$ $(p<0.01)$ level as shown on the ANOVA table (Table 2). In contrast to what was observed when the results were compared across the families, the comparison with different protocols gave 


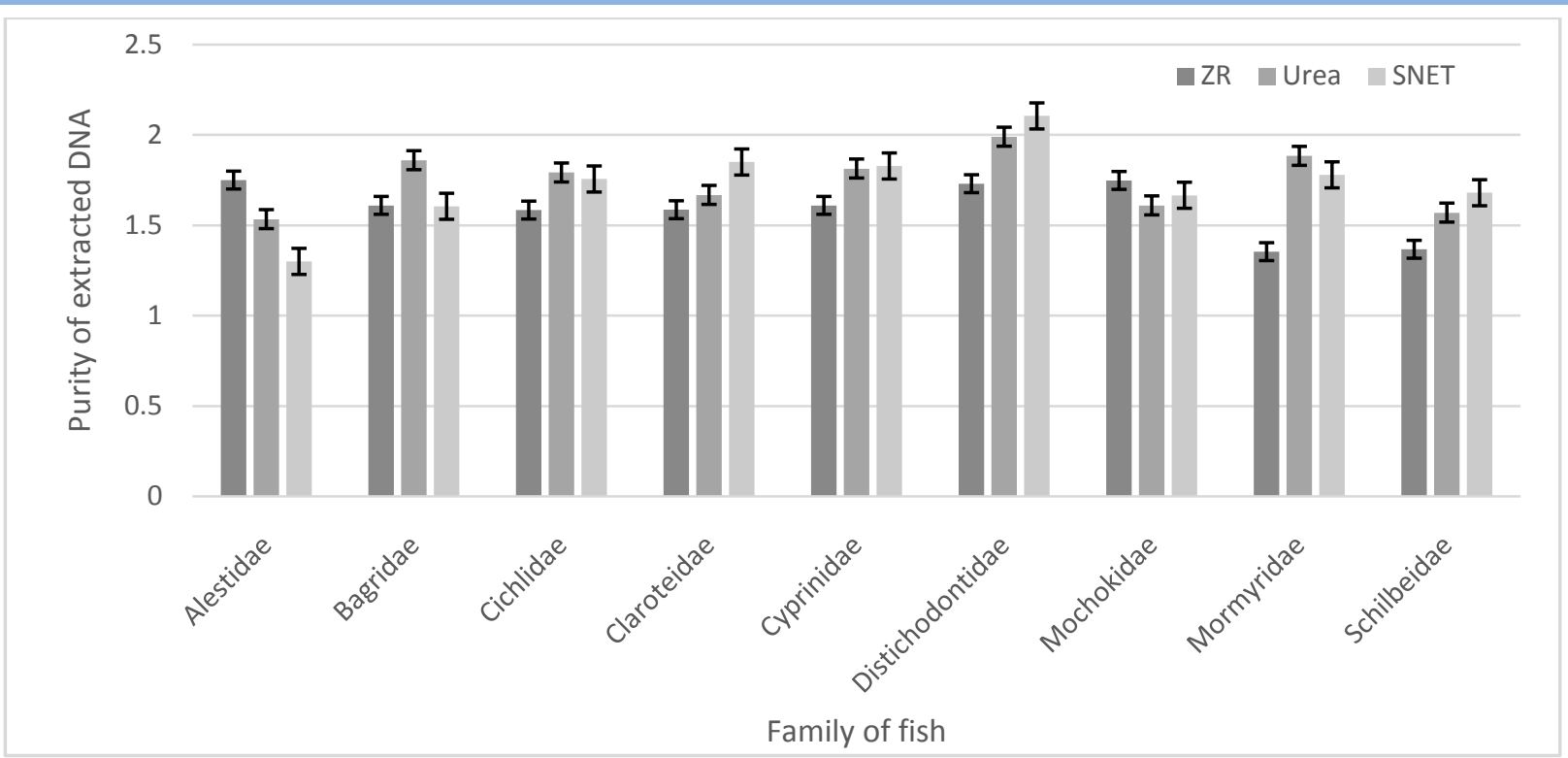

Figure 6 Mean values of DNA Purity for 3 extraction protocols compared across the fish families.

Table 4 Mean separations result comparing the concentration and purity of the extracted DNA among the 3 extraction protocols

\begin{tabular}{ccc|} 
Protocol & Concentration & Purity \\
\hline ZR & $30.591 \pm 90.313^{\mathrm{c}}$ & $1.582 \pm 0.067^{\mathrm{a}}$ \\
\hline Urea & $705.492 \pm 90.313^{\mathrm{a}}$ & $1.752 \pm 0.067^{\mathrm{a}}$ \\
\hline SNET & $562.219 \pm 90.313^{\mathrm{b}}$ & $1.727 \pm 0.067^{\mathrm{a}}$ \\
\hline
\end{tabular}

Values represent mean \pm standard error. Values along the same column with the same superscript are not significantly different at 5\% $(p>0.05)$ level.

Table $5 \mathrm{~T}$-Test result comparing the purity for the 3 extraction protocols with the standard value

\begin{tabular}{|cccccc|} 
Protocols & $\mathrm{t}$ & $\mathrm{df}$ & $\begin{array}{c}\mathrm{p}- \\
\text { value }\end{array}$ & Mean & Standard Value \\
\hline ZR & -4.577 & 54 & $.000^{* *}$ & 1.582 & 1.80 \\
\hline Urea & -1.383 & 54 & $.172^{\text {ns }}$ & 1.752 & 1.80 \\
\hline SNET & -1.039 & 54 & $.304^{\text {ns }}$ & 1.727 & 1.80 \\
\hline
\end{tabular}

**: Significant at $1 \%(\mathrm{p}<0.01)$ level; ns: Not significant at $5 \%(\mathrm{p}>0.05)$ level

credible variation in extracted DNA. This has been said that the efficiency of DNA extraction protocol plays important role in DNA recovery according to Oosting et al. (2020).

These results also showed that purity of the extracted DNA ranged from 1.58 to 1.75 with the highest purity observed in Urea protocol while the least purity was observed in ZR protocol. However, statistical analysis revealed that the purity of the extracted DNA did not differ significantly among the 3 extraction protocols at $5 \%$ ( $>0.05$ ) level. We then inferred that though the DNA quantity or concentration may differ among protocols employed for extraction, their purity may not if the protocols are strictly followed by the experiment. This is because they have all been optimized for good DNA quality. In addition to this, as much as DNA purity is pertinent to molecular studies, Jasbeer et al. (2009) has observed that sufficient purity does not guarantee successful gene amplification in downstream analysis. Therefore, they opined that apart from having pure DNA in extraction, further investigation by amplification is required to ascertain the suitability of the recovered DNA for downstream analysis.

Furthermore, table 5 is the result of the T-test comparing the purity of the extracted DNA with the standard value for the 3 extraction protocols. The result showed that purity for ZR protocol, 1.582 was significantly lower than the standard value; 1.80 at $1 \%$ $(\mathrm{p}<0.01)$ level. Similarly, the purity for Urea SDS (1.752) and SNET protocol(1.727) were also reported to be lower than the standard value(1.80,) although these two values were not significantly different from the standard value at $5 \%(\mathrm{p}>0.05)$ level. This suggests that all the protocols used were good and they all produced good DNA quality/purity significantly close to the standard expected of a good protocol (Lagass-Pereira et al., 2016).

Hence, the quantity and quality of recovered DNA is largely dependent on the protocol used, strict adherence to manufacturer instructions, and the technical understanding of the researcher of the molecular biology experiment. This research has shown that Urea SDS yielded better results both in quantity and in quality. These results are in agreement with the findings of Chowdhury et al. (2016). Although, they reported that Urea SDS is a better method with DNA quality/purity only but not quantity/concentration. 


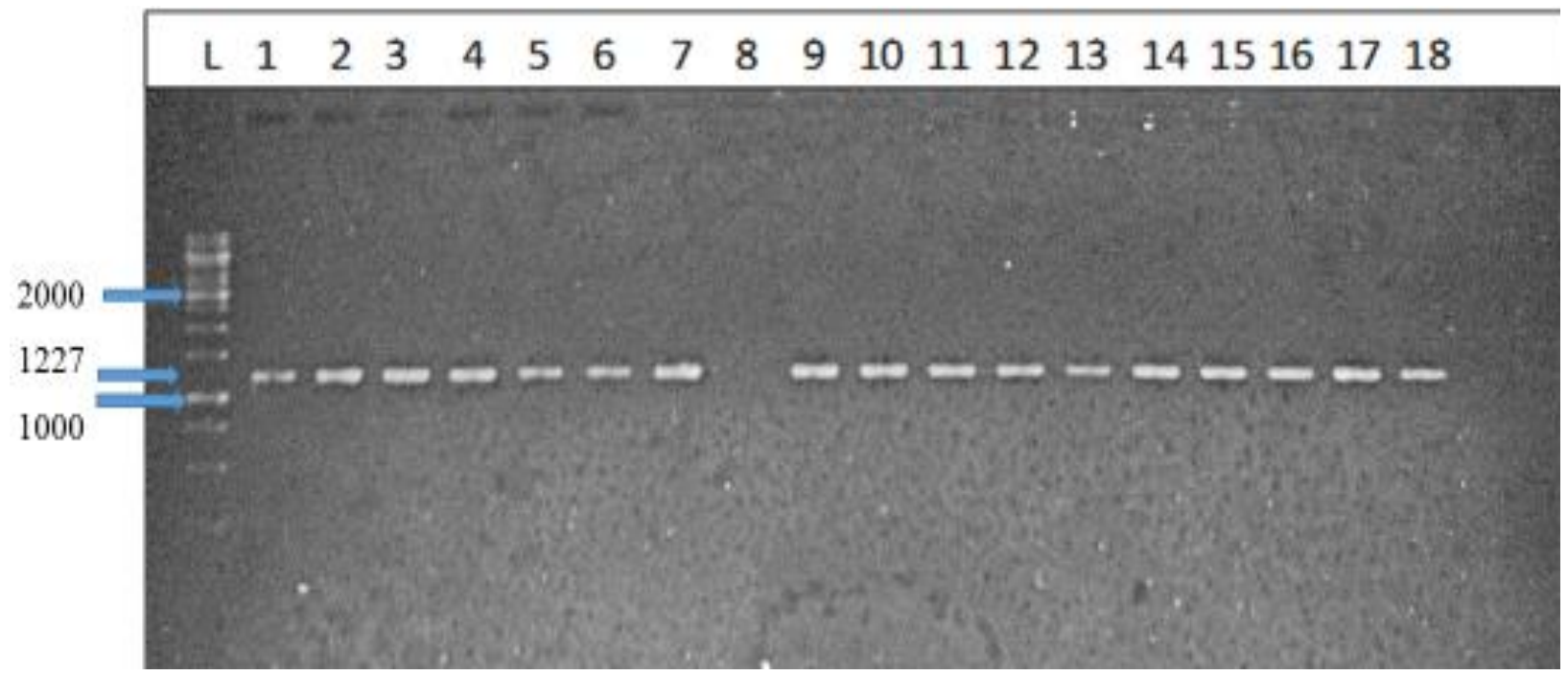

Figure 7 Agarose Gel image of amplification product from UREA-SDS protocol using Cytochrome B gene region with 1227 bp product size.

According to the submission of Jasbeer et al. (2009), further investigation through gene amplification is necessary to fully establish the suitability of DNA for further studies. Cytochrome B gene region was used to amplify the extracted DNA. The Cytochrome gene region has a size $1227 \mathrm{bp}$. The observation of DNA good quality and quantity recovered from Urea SDS protocol necessitates the confirmation of its suitability for downstream analysis via Cytochrome B gene amplification. The gel picture of figure 7 is the result of the amplification of the gene. The gene region was recognized on the DNA sample/template at the required location as shown with clear bands on the gel picture. This proofs unequivocally the DNA extracted through Urea SDS protocol is adequately suitable for downstream analysis

\section{Conflicts of interest}

The authors declare that they have no conflicts of interest.

\section{Conclusion}

Three protocols were used for the analysis: Zymo Research Kit (ZR), modified conventional SNET method, and modified UreaSDS method. The analysis revealed that variation in biomolecular composition such as polysaccharides and lipids across fish families are not the determinant of DNA purity and concentration recovery. In the same way, ecological distribution and other variations in environmental perturbations are not responsible for the purity or quantity of recovered DNA. Among the various tested protocols, the most significant is the efficiency of the used protocol and the technical handling of the experiment. Among the three protocols used, Urea SDS is best in quality and quantity and is therefore recommended for fish DNA further analysis.

\section{References}

Adaka GS, Nlewadim AA, Udoh JP (2016). Diversity and Distribution of Freshwater Fishes in Oguta Lake, Southeast Nigeria. Advances in Life Science and Technology 26:25-32.

April J, Mayden RL, Hanner RH, Bernatchex L (2011) Genetic calibration of species diversity among North America's freshwater fishes. PNAS 108(26):10602-10607.

Bruyn M, Parenti LR, Carvalho GR (2011) Successful extraction of DNA from archived alcohol-fixed white-eye fish specimens using an ancient DNA protocol. Journal of Fish Biology 78: 20742079. doi:10.1111/j.1095-8649.2011.02975.

Chowdhury MM, Rahman AS, Nahar L, Rahman M, Al Reza H, Ahmed MDS (2016) Efficiency of Different DNA Extraction Methods for Fish Tissues: A Comparative Analysis. IOSR Journal of Pharmacy and Biological Sciences 11(3):11-15.

Dwiyitno D, Hoffman S, Parmentier K, Keer CV (2018) Method Comparison of DNA Isolation and Quantification for Fish and Seafood Authenticity Determination. Squalen Bulletin of Marine and Fisheries Postharvest and Biotechnology 13 (3): 115-124.

Espinoza GJ, Michael Poland J, Alvarado Bremer JR (2017) Genotyping live fish larvae: Non-lethal and noninvasive DNA isolation from 3-5 day old hatchlings BioTechniques 63:181-186 (October 2017) doi 10.2144/000114598.

Habib MAB, Yusoff FM, Phang SM,MohamedS(2003)Growth and nutritional values of Moina micrura fed on Chlorella vulgaris grown in digested palm oil mill effluent. Asian Fisheries Science16:107-119. 
Jasbeer K, Son R, Ghazali MF, Cheah YK (2009) Real-time PCR evaluation of seven DNA extraction methods for the purpose of GMO analysis. International Food Research Journal 16: 329-341.

Kandyliari A, Mallouchos A, Papandroulakis N, Golla JP, Lam TT, Sakellari A, Karavoltsos S, Vasiliou V, Kapsokefalou M (2020) Nutrient Composition and Fatty Acid and Protein Profiles of Selected Fish By-Products. Foods (9):190; doi:10.3390/foods9020190.

Keele J, Carmon J, Pucherelli SF, Hosler D (2014). Identification of Unknown Organisms by DNA Barcoding: A Molecular Method for Species Classification. Research and Development Office Invasive Mussels Final Report 2014-01 (0045).

Keriko JM, Chege CW, Magu MM, Mwachiro EC, Murigi AN, Githua MN, Kareru PG (2010) Fish lipid contents and classes of selected fish species found in Lake Naivasha (Kenya) and the fish feeding habits of the lake's inhabitants. African Journal of Pharmacy and Pharmacology 4(10):745-753.

Lagass-Pereira L, Damasceno JDS, Da-Vitoria EL, SilvaMH, Farro APC (2016) Comparison of DNA extraction protocols for different marine fish tissues. Pan-American Journal of Aquatic Sciences 11(2):135-142.

Majumder DAN, Hassan L, Rahim MA, Kabir MA (2011)Development of an efficient protocol for genomic DNA extraction from mango (Mangifera indica). Bioscience 3(3):105111.doi: 10.13057/nusbiosci/n030301.

Megarani DV, Nugroho HA, Andarini ZP, Surbakti YDRBR, Widayanti R (2020) Genetic characterization and phylogenetic study of Indonesian indigenous catfish based on mitochondrial cytochrome B gene, Veterinary World 13(1): 96-103.

Muhammad H, Iqbal Z, Iqbal MU, Younas T, Bashir Q (2016) An efficient method of DNA extraction from fish fin. Pakistan Journal of Agricultural Sciences 53(4):843-850 DOI: 10.21162/PAKJAS/16.3998.

Naeem M, Hassan S, Masud S, Ali Q, Hayat S, Naeem AD, Naeem Z (2020) Comparative analysis of genomic DNA extraction protocols: Maxi-preparation of quality DNA for genetic evaluation and phylogenetic studies. Genetics and Molecular Research 19 (1): 1-9 gmr16039976.

Nelson JS, Crossman EJ, Espinosa-Pérez H, Findley LT, Gilbert CR, Lea RN, Williams JD (2004) Common and Scientific Names of Fishes from the United States, Canada, and Mexico, (6th Ed.). American Fisheries Society, Pp. 386.
Nwakanma C, Ude G, Unachukwu MN(2015).The Use of DNA Barcoding in Identification of Genetic Diversityof Fish in Ugwu-Omu Nike River in Enugu. Nigerian Journal of Biotechnology29:27 - 33.

Oosting T, Hilario E, Wellenreuther M, Ritchie PA (2020) DNA degradation in fish: Practical solutions and guidelines to improve DNA preservation for genomic research. Ecology and Evolution 00:1-9. DOI: 10.1002/ece3.6558.

Osibona AO, Kusemiju K, Akande GR (2009) Fatty acid composition and amino acid profile of two freshwater species, African catfish (Clarias gariepinus) and Tilapia (Tilapia zillii). African Journal of Food, Agriculture, Nutrition and development9 (1): 608-621.

Parpinelli RS, Ribeiro RP(2009) Estudocomparativo de protocolos de extração deDNA em diferentes tecidos de tilápia do nilo(Oreochromis niloticus). Global Science and Technology 2:22-33.

Pereira JC, Chaves R, Bastos E, Leitão A, Guedes-Pinto H (2011)An Efficient Method for Genomic DNA Extraction from Different Molluscs Species. International Journal of Molecular Science12: 8086-8095. doi:10.3390/ijms12118086.

Piskata Z, Pospisilova E, Borilova G (2017) Comparative study of DNA extraction methods from fresh and processed yellow fin tuna muscle tissue. International Journal of Food Properties20(1): S430S443. doi: 10.1080/10942912.2017.1297953.

Rodriguez-Ezpeleta N, Mendibil I, Álvarez P, Cotano U(2013) Effect of fish sampling and tissue storage conditions in DNA quality: considerations for genomics studies. Revista de Investigación Marina, AZTI-Tecnalia20(6): 77-87.

Sajali NS, Wong SC, Hanapi UK, Bakar SA, Tasrip NA, Desa NM (2018) The challenges of DNA extraction in different assorted food matrices. Journal of Food Science 83(10):2408-2414 doi: 10.1111/1750-3841.14338.

Wasko AP, Martin C, Oliveira C, Forresti F (2003) Nondestructive genetic sampling in fish: An improved method for DNA extraction from fish fins and scales. Hereditas138: 161-165.

Weigt LA, Baldwin CC, Driskell A, Smith DG, Ormos A, Reyier EA (2012) Using DNA Barcoding to Assess Caribbean Reef Fish Biodiversity: Expanding Taxonomic and Geographic Coverage. PLoS ONE7(7): 1-7. doi:10.1371/journal.pone.0041059.

Widayanti R, Haryanto A, Artama WT, Pakpahan S (2019) Genetic variation and phylogenetic analysis of Indonesian indigenous catfish based on mitochondrial cytochrome oxidase subunit III gene. Veterinary World 12(6): 896-900. 